
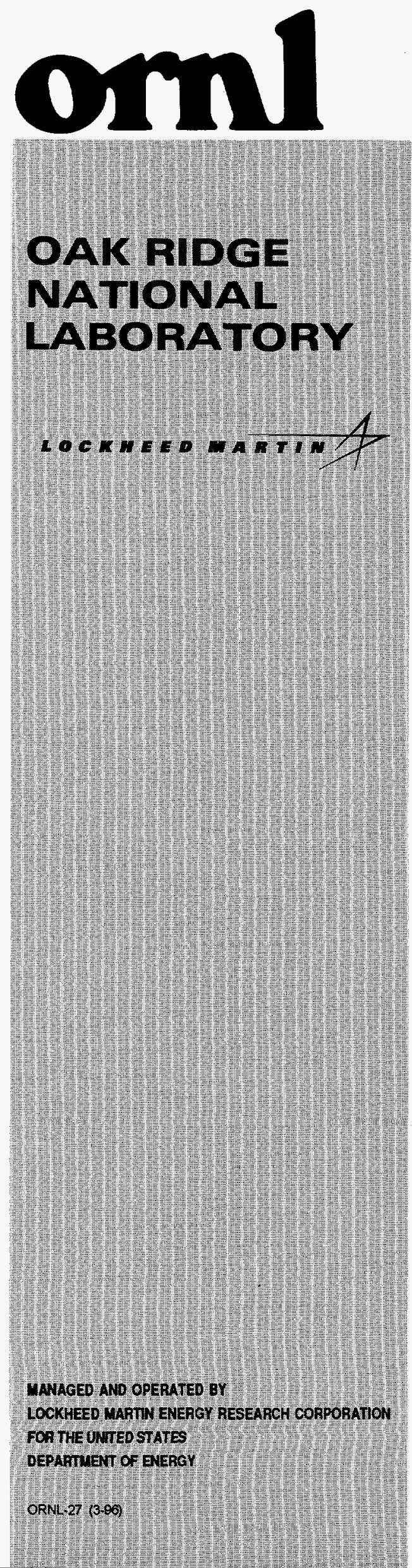

\title{
Radiological Survey Results for the R. P. Adams Company Property, Tonawanda, New York (TNY003)
}

\author{
S. P. McKenzie \\ M. S. Uziel \\ R. F. Carrier
}

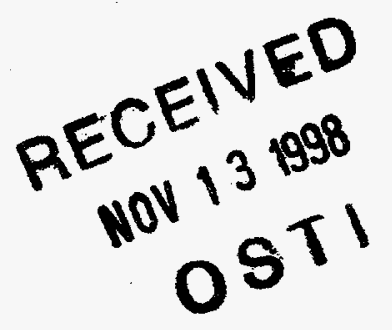


This report has been reproduced directy from the best available copy.

Avalable to DOE and DOE contractors from the Office of Scientific and Technical Information, P.O. Box 62, Oak Ridge, TN 37831; prices available from $423-576-8401$.

Available to the public from the National Technical Information Service, U.S. Department of Commerce, 5285 Port Royal Rd., Springfield, VA 22161.

This report was prepared as an account of work sponsored by an agency of the United States Government. Neither the United States Government nor any agency thereof, nor any of their employees, makes any warranty, express or implied, or assumes any legal liability or responsibility for the accuracy, completeness, or usefulness of any information, apparatus, product, or process disclosed, or respresents that its use would not infringe privately owned rights. Reference herein to any specific commercial product, process, or service by trade name, trademark, manufacturer, or otherwise, does not necessarily constitute or imply its endorsement, recommendation, or favoring by the United States Government or any agency thereof. The views and opinions of authors expressed herein do not necessarily state or reflect those of the United States Government of any agency thereof. 


\section{DISCLAIMER}

Portions of this document may be illegible in electronic image products. Images are produced from the best available original document. 
Prepared for the U.S. ARMY CORPS OF ENGINEERS, Buffalo District

(Budget and Reporting Code 43WM1 1202; Agency Code DAG)

\title{
Radiological Survey Results for the R. P. Adams Company Property, Tonawanda, New York (TNY003)
}

\author{
S. P. McKenzie, M. S. Uziel, and R. F. Carrier
}

Date Issued-November 1998

Investigation Team

R. D. Foley - Meısurement Applications and Development Manager

M. E. Murtay - FUSRAP Project Director

S. P. McKenzie - Survey Team Leader

Survey Team Members

J. P. Abston

D. E. Rice

G. H. Cofer

D. A. Roberts

R. C. Gosslee

R. E. Rodriguez

S. P. McKenzie

D. A. Rose

M. E. Murray

J. Wade

W. Winton

Work performed by the

MEASUREMENT APPLICATIONS AND DEVELOPMENT GROUP

LIFE SCIENCES DIVISION

Prepared by the

OAK RIDGE NATIONAL LABORATORY

Clak Ridge, Tennessee 37831-6285

managed by

LOCKHEED MARTIN ENERGY RESEARCH CORP.

for the

U.S. DEPARTMENT OF ENERGY

under contract DE-AC05-960R22464 



\section{CONTENTS}

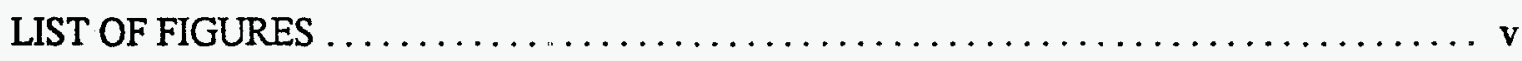

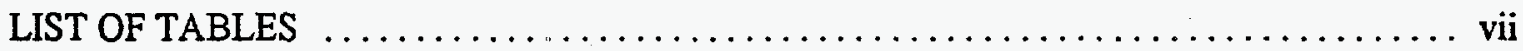

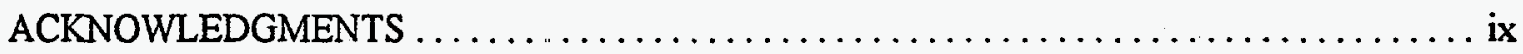

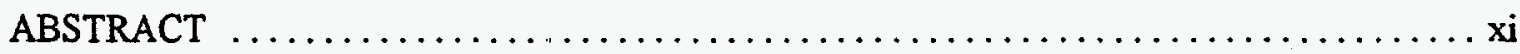

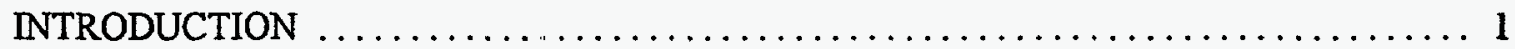

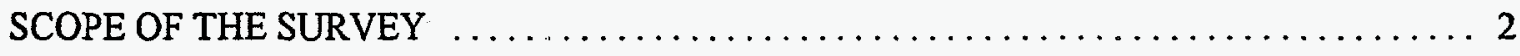

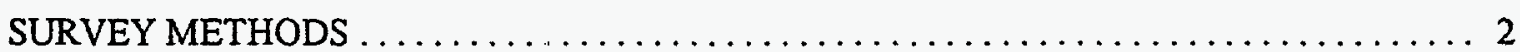

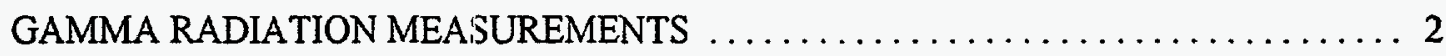

SOIL SAMPLING AND ANALYSES $\ldots \ldots \ldots \ldots \ldots \ldots \ldots \ldots \ldots \ldots \ldots \ldots \ldots \ldots \ldots$

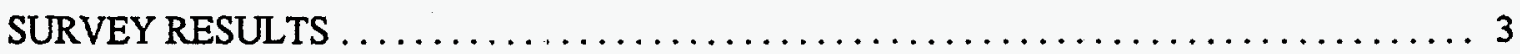

GAMMA EXPOSURE RATE MEASUREMENTS $\ldots \ldots \ldots \ldots \ldots \ldots \ldots \ldots \ldots \ldots$

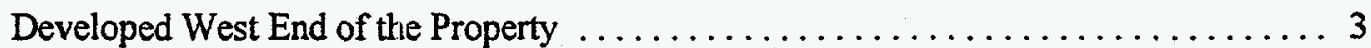

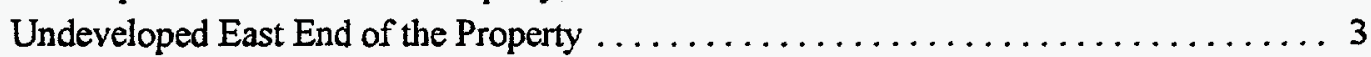

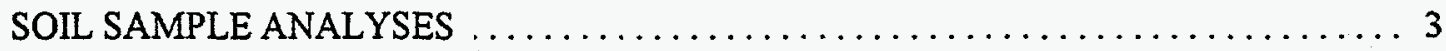

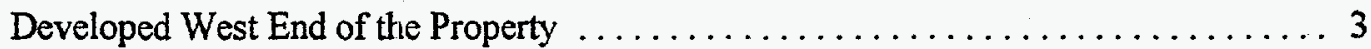

Undeveloped East End of the Property . . . . . . . . . . . . . . . . . . . . 4

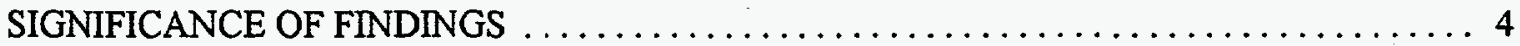

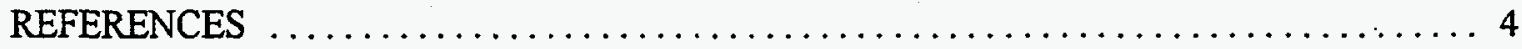




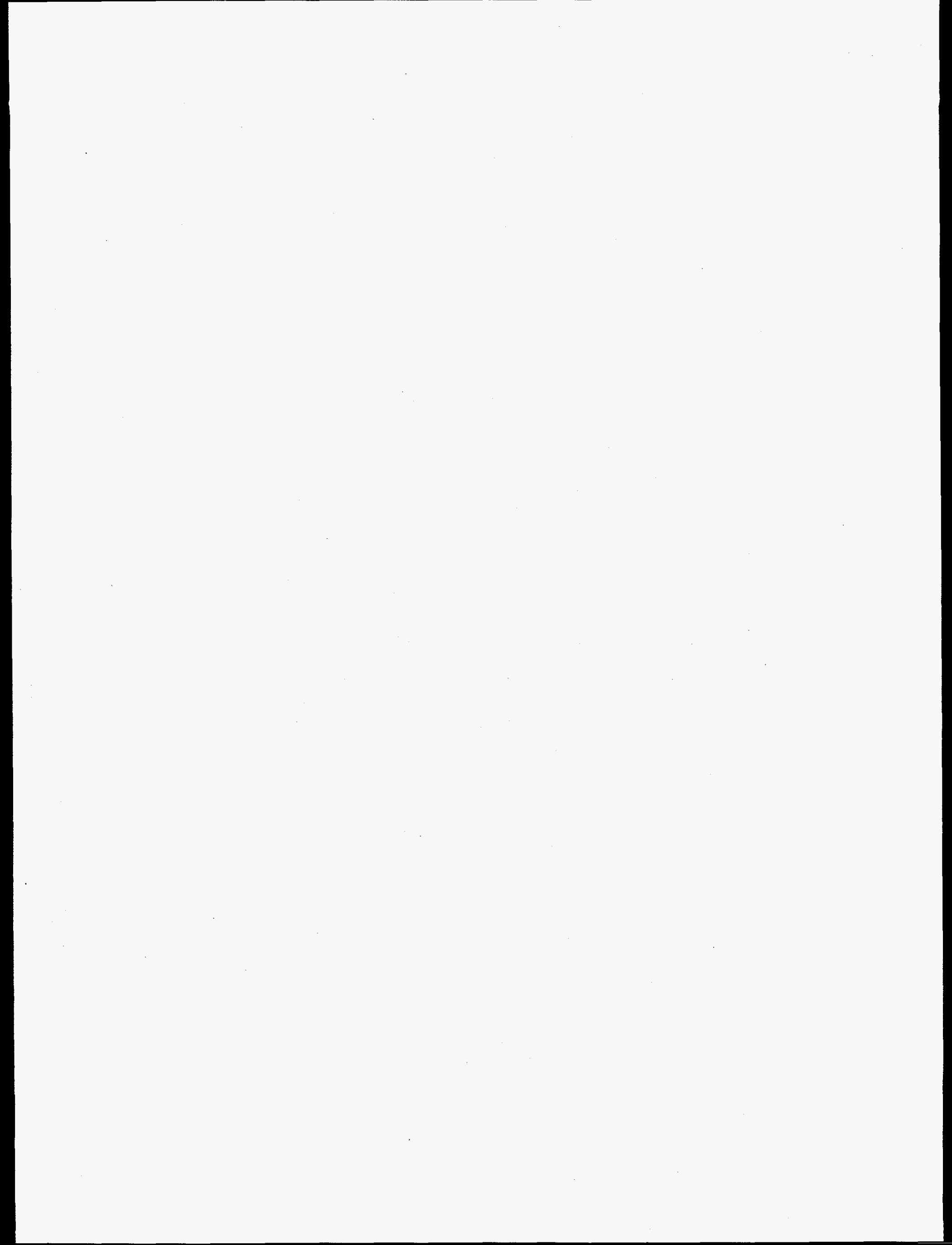




\section{LIST OF FIGURES}

1 Diagram showing general location of the R. P. Adams property

in relation to the former Linde plant site in Tonawanda, New York

2 Diagram showing developed and undeveloped parts of the

R. P. Adams property.

3 Diagram showing systematic and biased soil sampling locations

on the developed portion of the R. P. Adams property

4 Diagram showing systematic and biased soil sampling locations

on the undeveloped portion of the R. P. Adams property

5 Diagram showing surface and 1-m gamma exposure rates on the developed portion of the R. P. Adams property

6 Diagram showing surface and 1-m gamma exposure rates on the undeveloped portion of the R. P. Adams property 



\section{LIST OF TABLES}

1 Applicable guidelines for protection against radiation

2 Background radiation levels and concentrations of selected radionuclides in soil near Torawanda, New York

3 Concentrations of selected radionuclides in soil samples collected from the developed west portion of the R. P. Adams property,

Tonawanda, New York

4 Concentrations of selected radionuclides in soil samples collected from the undeveloped east portion of the R. P. Adams property, Tonawanda, New York 



\section{ACKNOWLEDGMENTS}

The portion of this project completed after October 1, 1997, was sponsored by the U.S. Army Corps of Engineers, Buffalo District. Prior to that date, the project was sponsored by the Office of Environmental Restoration, U.S. Department of Energy, under contract DE-AC05-840R21400 with Martin Marietta Energy Systems, Inc., and DE-AC05-960R22464 with Lockheed Martin Energy Research Corp.

The authors wish to acknowledge the contributions of J. P. Abston, G. H. Cofer, R. L. Coleman, R. C. Gosslee, M. E. Murray, D. E. Rice, D. A. Roberts, R. E. Rodriguez, D. A. Rose, J. Wade, W. Winton, and J. K. Williams of the Measurement Applications and Development Group, Oak Ridge National Laboratory, for sample preparation and participation in the analyses, editing, and reporting of data for this survey. The authors also wish to thank David Henning and Donald Felt of the R. P. Adams Company, Inc. 



\begin{abstract}
At the request of the U.S. Dlepartment of Energy (DOE), a team from Oak Ridge National Laboratory conducted a radiological survey of property belonging to the R. P. Adams Company, Inc., Tonawanda, New York. The survey was performed in November 1995 and May and July 1996. The purpose of the survey was to determine if radioactive residuals had migrated, or been redistributed, from the former Linde property to the south onto the R. P. Adams property. The Linde Air Products Division of Union Carbide Corporation, Tonawanda, New York, had used radioactive materials at that location for work performed under government contract from 1942 through 1948.

The survey was performed in response to Formerly Utilized Sites Remedial Action Program (FUSRAP) requirements. These requirements dictate that the radiological status of certain vicinity properties shall be assessed and documented according to prescribed procedures prior to certification of the property for release for unrestricted use. Such release can only be granted if the property is found to be within current applicable authorized limits.

The survey included a gamma scan of accessible areas in both the developed and the undeveloped portions of the property and the collection and radionuclide analysis of soil samples. A comparison of these data to the current DOE guidelines shows that all radionuclide concentrations and radioactivity levels found on the property are below the current guidelines. Therefore, this property should not be included in the FUSRAP program for remediation.
\end{abstract}




\section{Radiological Survey Results for the R. P. Adams Company Property, Tonawanda, New York (TNY003)*}

\section{INTRODUCTION}

From 1942 through approximately 1948, the Linde Air Products Division of Union Carbide Corporation, Tonawanda, New York, was one of many companies performing work associated with the development of nuclear energy for defense-related projects. This work was conducted under government contract to the Manhattan Engineer District (MED) and the Atomic Energy Commission (AEC). During the first 3 years, pitchblende ore from the Belgian Congo and concentrates from the Colorado Plateau ore were converted to $\mathrm{U}_{3} \mathrm{O}_{8}$. A second process yielding $\mathrm{UO}_{2}$ was conducted for about a year, and a third process, converting $\mathrm{UO}_{2}$ to green salt $\left(\mathrm{UF}_{4}\right)$, operated during World War II and the following 2 years. Linde also developed and produced barrier material for the Oak Ridge Gaseous Diffusion Plant. Other contracts have been identified, but the exact nature of the work involved is unknown. ${ }^{1}$

As a result of these and similar activities, equipment, buildings, and land at some of the sites became radiologically contaminated resulting in low levels of contamination on the properties. At contract termination, sites used by contractors were decontaminated in accordance with the standards and survey methods in use at that time. Since the original assessments, radiological criteria and guidelines for the release of such sites for unrestricted use have become more stringent. In some instances, records documenting decontamination efforts cannot be found, and the final radiological conditions of the site cannot be adequately determined. As a result, the Formerly Utilized Sites Remedial Action Program (FUSRAP) was established in 1974 to identify these formerly used sites and to reevaluate their radiological status. ${ }^{1}$ The radiological assessment showing the presence of radioactive residuals at the Linde site was performed in $1978 .^{2}$

Occasionally, nearby private and commercial properties also became contaminated through migration or redistribution of the radioactive residuals from the original site. ${ }^{3}$ The radiological survey detailed in this report was performed under the FUSRAP program as a follow-up to earlier investigations and as a precaution to insure that no residual radioactive materials exceeding current DOE guidelines were present on the R. P. Adams property. The purpose of the survey was to determine if any contamination may have been transferred from the Linde site onto adjacent property belonging the R. P. Adams Company, Inc. The relative locations of the two properties are diagramed on Fig. 1.

The R. P. Adams site lies adjacent to the northern border of the former Linde Plant and extends from East Park Drive to the Niagara Mohawk Power Corporation right-of-way (Fig. 1). The development, production, and management activities of R. P. Adams are conducted in the buildings at the western end of the surveyed property. The eastern half of the site remained undeveloped at the time of the survey (Fig. 2). Most of the data presented in this report was obtained in May and July 1996. The original walkover on the developed portion of the property was conducted in November 1995.

\footnotetext{
*The survey was performed by members of the Measurement Applications and Development Group of the Life Sciences Division at Oak Ridge National Laboratory.
} 


\section{SCOPE OF THE SURVEY}

The radiological survey included (1) a surface gamma scan of accessible areas of the property, (2) measurement of 1-m gamma exposure rates at soil sampling locations, and (3) collection and radionuclide analysis of systematic and biased soil samples. Systematic samples were collected in a systematic order without regard to radiation level; biased soil samples were collected at locations of slightly elevated gamma levels.

\section{SURVEY METHODS}

A comprehensive description of the methods and instrumentation used in this survey and in the laboratory analyses is given in Procedures Manual for the ORNL Radiological Survey Activities (RASA) Program, ORNL/TM-8600 (April 1987) ${ }^{4}$ and Measurement Applications and Development Group Guidelines, ORNL-6782 (January 1995). ${ }^{5}$

Separate grids were established over the developed and the undeveloped portions of the property to enable the precise location of measurements and samples (Figs. 3 and 4). The southwestern corner of each property was designated as $0 \mathrm{~N}, 0 \mathrm{E}$. A sample was then located by number of feet directly north and then directly east of the southwest corner. For example, sample S70 (Fig. 3 and Table 3; 70N, 200E) on the developed west portion of the R. P. Adams property was collected 70 feet north and 200 feet east of the southwest corner (ON, OE) of the developed part. Sample S16 (Fig. 4 and Table 4; 50N, 840E) on the undeveloped east potion of the R. P. Adams property was collected $50 \mathrm{ft}$ north and 840 feet east of southwest corner $(0 \mathrm{~N}, 0 \mathrm{E})$ of the undeveloped area.

\section{GAMMA RADIATION MEASUREMENTS}

Gamma radiation levels were determined using portable $\mathrm{NaI}$ gamma scintillation meters. Because $\mathrm{NaI}$ gamma scintillators are energy dependent, measurements of gamma radiation levels in counts per minute are normalized to pressurized ionization chamber (PIC) measurements to estimate gamma exposure rates in $\mu \mathrm{R} / \mathrm{h}$.

\section{SOIL SAMPLING AND ANALYSES}

Surface and subsurface soil samples were systematically collected (i.e., without regard to gamma radiation levels) at grid locations shown on Figs. 3 and 4. Additional samples were collected at locations with elevated gamma radiation levels and designated as "biased" (Figs. 3 and 4).

A gradient approach was applied to the soil sampling operations with the highest concentration of samples taken along the fence line nearest the former Linde plant site; fewer samples were collected as sampling operations were moved north away from the Linde site. Work involving uranium at the Linde site was conducted in the southeast quadrant and, since the land is fairly level, it was assumed that any contamination entering the R. P. Adams property would most probably have come from the south. 


\section{SURVEY RESULTS}

DOE guidelines are summarized in Table 1. Typical background radiation levels for the Tonawanda, New York, area are presented in Table 2. These data are provided for comparison with survey results presented in this section. All direct measurement results presented in this report are gross readings; background radiation levels have not been subtracted. Similarly, background concentrations have not been subtracted from radionuclide concentrations measured in soil samples.

\section{GAMMA EXPOSURE RATE MEASUREMENTS}

\section{Developed West End of the Property}

Gamma exposure rates in accessible areas of the developed portion of the property ranged from 7 to $11 \mu \mathrm{R} / \mathrm{h}$ at the surface and from 7 to $10 \mu \mathrm{R} / \mathrm{h}$ at $1 \mathrm{~m}$ above the ground surface (Fig. 5). The highest gamma exposure measurements found at four biased sampling locations ranged from 11 to $13 \mu \mathrm{R} / \mathrm{h}$ at the ground surface and from 9 to $11 \mu \mathrm{R} / \mathrm{h}$ at $1 \mathrm{~m}$ above the surface. These values are at or near background levels typically found in the Tonawanda area (Table 2).

\section{Undeveloped East End of the Property}

The undeveloped east end of the R. P. Adams property is approximately $3 / 8$ mile long and $100 \mathrm{yd}$ wide. Scanning was very difficult or impossible in some parts, which contained low-lying swampy, marshy areas with some standing water. More than one-half of the undeveloped area was cleared of trees and covered with grass although parts of the grassy area contained thorny bushes and brush (Fig. 2). Approximately $90 \%$ of the cleared area was accessible. The eastern most half was heavily woody and also contained marshy places and standing water. Approximately $50 \%$ of the wooded area was accessible.

The gamma scan of accessible areas in the east end revealed general exposure rates ranging from 8 to $12 \mu \mathrm{R} / \mathrm{h}$ at the surface and 7 to $12 \mu \mathrm{R} / \mathrm{h}$ at $1 \mathrm{~m}$ (Fig. 6). Higher surface measurements of 13 and $18 \mu \mathrm{R} / \mathrm{h}$ at the surface and $13 \mu \mathrm{R} / \mathrm{h}$ at $1-\mathrm{m}$ can probably be attributed to natural radioactive substances present in the outcroppings of slag. Slag was most evident in a 300-ft-long area at the eastern end of the property near the southern fence.

\section{SOIL SAMPLE ANALYSES}

\section{Developed West End of the Property}

The results of the soil sample analyses on 33 systematic and 4 biased surface soil samples $(0-15 \mathrm{~cm})$ from the developed section of the property are given in Table 3. Sample locations are shown on Fig. 3. Concentrations of ${ }^{238} \mathrm{U}$ ranged from 0.95 to $3.0 \mathrm{pCi} / \mathrm{g}$ in 32 systematic samples and 3 biased samples. One systematic sample (S6I) contained $4.3 \pm 0.5 \mathrm{pCi} / \mathrm{g}{ }^{238} \mathrm{U}$; one biased sample (B15) contained $9.7 \pm 3 \mathrm{pCi} / \mathrm{g}$. All samples were well below the $\mathrm{DOE}$ guideline values for ${ }^{238} \mathrm{U}$ at this site (see Table 1). Concentrations of ${ }^{226} \mathrm{Ra}$ ranged from 0.90 to $2.2 \mathrm{pCi} / \mathrm{g}$ and concentrations of ${ }^{232} \mathrm{Th}$ ranged from 0.65 to $1.3 \mathrm{pCi} / \mathrm{g}$ in all samples, systematic and biased. These concentrations are similar to normal background soil concentrations of ${ }^{226} \mathrm{Ra}$ and ${ }^{232} \mathrm{Th}$ for the Tonawanda area (Table 2) and well below the DOE guideline value of $5 \mathrm{pCi} / \mathrm{g}$ over the first $15 \mathrm{~cm}$ (Table 1). 
Undeveloped East End of the Property

The results of the soil sample analyses on 71 samples, systematic plus biased, from the undeveloped portion of the property are given in Table 4. Sample locations are shown on Fig. 4. Samples were collected from both surface $(0-15 \mathrm{~cm})$ and subsurface $(15-45 \mathrm{~cm})$ areas. Concentrations of ${ }^{238} U$ ranged from 0.74 to $6.6 \mathrm{pCi} / \mathrm{g}$ in 66 samples. Samples S10, B8A, B8B, B10, and B11B, collected in the southeast corner (Fig. 4), ranged from 8.5 to $16 \mathrm{pCi} / \mathrm{g}$. All samples were well below the DOE guideline values for ${ }^{238} \mathrm{U}$ at this site (see Table 1 ). Concentrations of ${ }^{226} \mathrm{Ra}$ ranged from 0.80 to $3.9 \mathrm{pCi} / \mathrm{g}$ and concentrations of ${ }^{232} \mathrm{Th}$ ranged from 0.34 to $3.5 \mathrm{pCi} / \mathrm{g}$ in all samples, systematic and biased, surface and subsurface. Some of these concentrations are greater than normal background soil concentrations of ${ }^{226} \mathrm{Ra}$ and ${ }^{232} \mathrm{Th}$ for the Tonawanda area (Table 2), but all are well below the DOE guideline value of $5 \mathrm{pCi} / \mathrm{g}$ averaged over the first $15 \mathrm{~cm}$ and $15 \mathrm{pCi} / \mathrm{g}$ averaged over $15-\mathrm{cm}$-thick soil layers more than $15 \mathrm{~cm}$ below the surface (Table 1).

\section{SIGNIFICANCE OF FINDINGS}

Results of this radiological survey indicate that no significant material originating at the Linde plant is located on the developed or undeveloped portions of the R. P. Adams Company property. Although some soil samples contained ${ }^{238} \mathrm{U}$ in concentrations greater than typical background levels found in the Tonawanda area, maximum ${ }^{238} \mathrm{U}$ levels of $16 \pm 1 \mathrm{pCi} / \mathrm{g}$ were well below the $\mathrm{DOE}$ guideline value of $30 \mathrm{pCi} / \mathrm{g}$ for this site. All measured gamma exposure rates were similar to normal background levels in the Tonawanda area. Therefore, this property should not be included in the FUSRAP program for remediation.

\section{REFERENCES}

1. U. S. Department of Energy, A Background Report for the Formerly Utilized Manhattan Engineer District/Atomic Energy Commission Sites Program, DOE/EV-0097, September 1980.

2. Oak Ridge Natl. Lab., Radiological Survey of the Former Linde Uranium Refinery, Tonawanda, New York, DOE/EV-005/5, UC-70, U.S. Department of Energy, Division of Environmental Control Technology, Formerly Utilized MED/AEC Sites Remedial Action Program, May 1978.

3. R. E. Rodriguez, M. E. Murray, and M. S. Uziel, Results of the Radiological Survey at the Town of Tonawanda Landfill, Tonawanda, New York (TNY001), ORNL/RASA-92/12, Martin Marietta Energy Systems, Inc., Oak Ridge Natl. Lab., October 1992.

4. T. E. Myrick, B. A. Berven, W. D. Cottrell, W. A. Goldsmith, and F. F. Haywood, Procedures Manual for the ORNL Radiological Survey Activities (RASA) Program, ORNL/TM-8600, Martin Marietta Energy Systems, Inc., Oak Ridge Natl. Lab., April 1987.

5. Measurement Applications and Development Group Guidelines, ORNL-6782, Martin Marietta Energy Systems, Inc., Oak Ridge Natl. Lab., January, 1995. 
ORNL-DWG $97-5638$

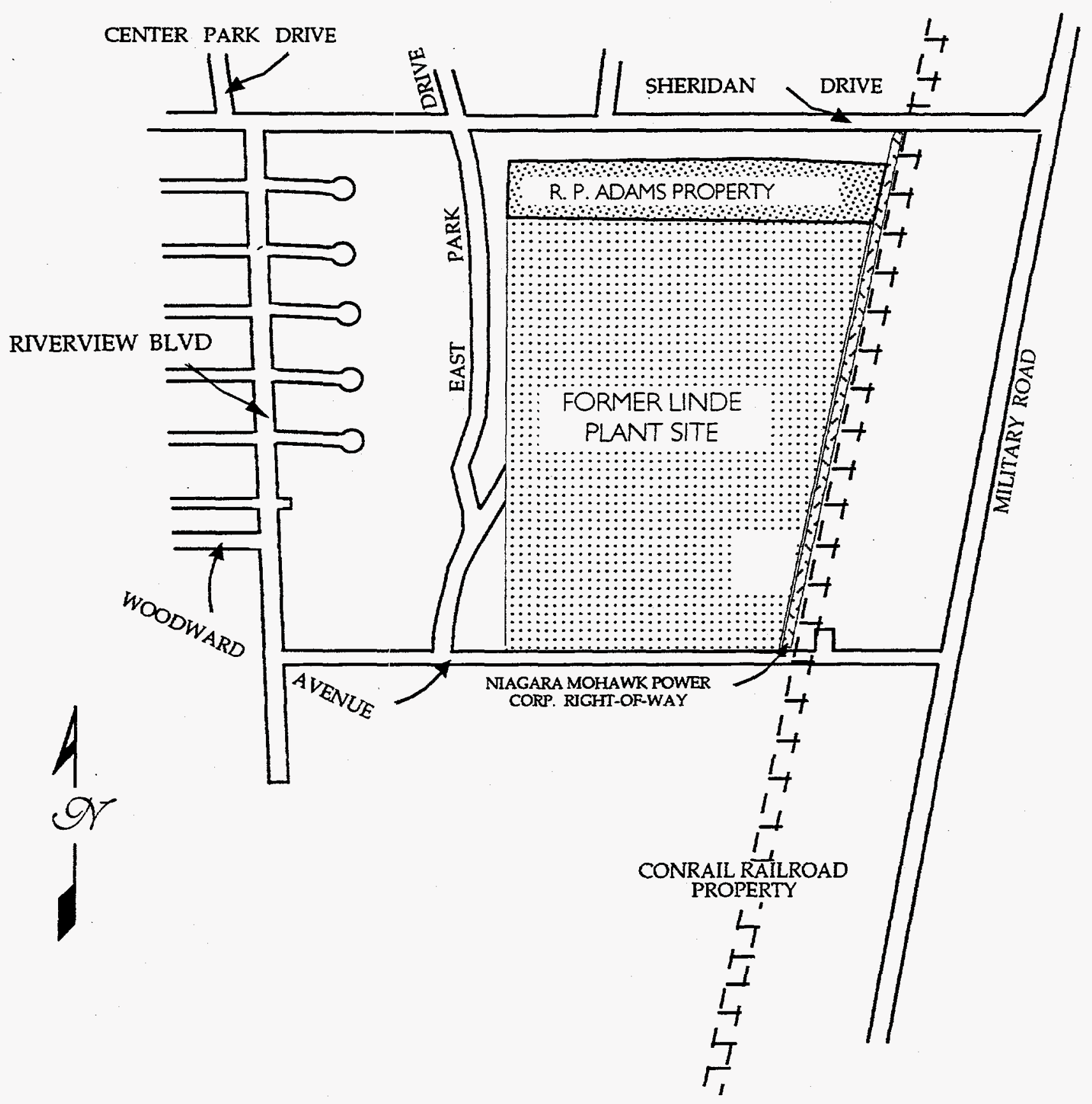

Fig. 1. Diagram showing general location of the R. P. Adams property in relation to the former Linde plant site in Tonawanda, New York. (Not to scale.) 


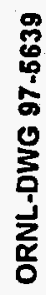
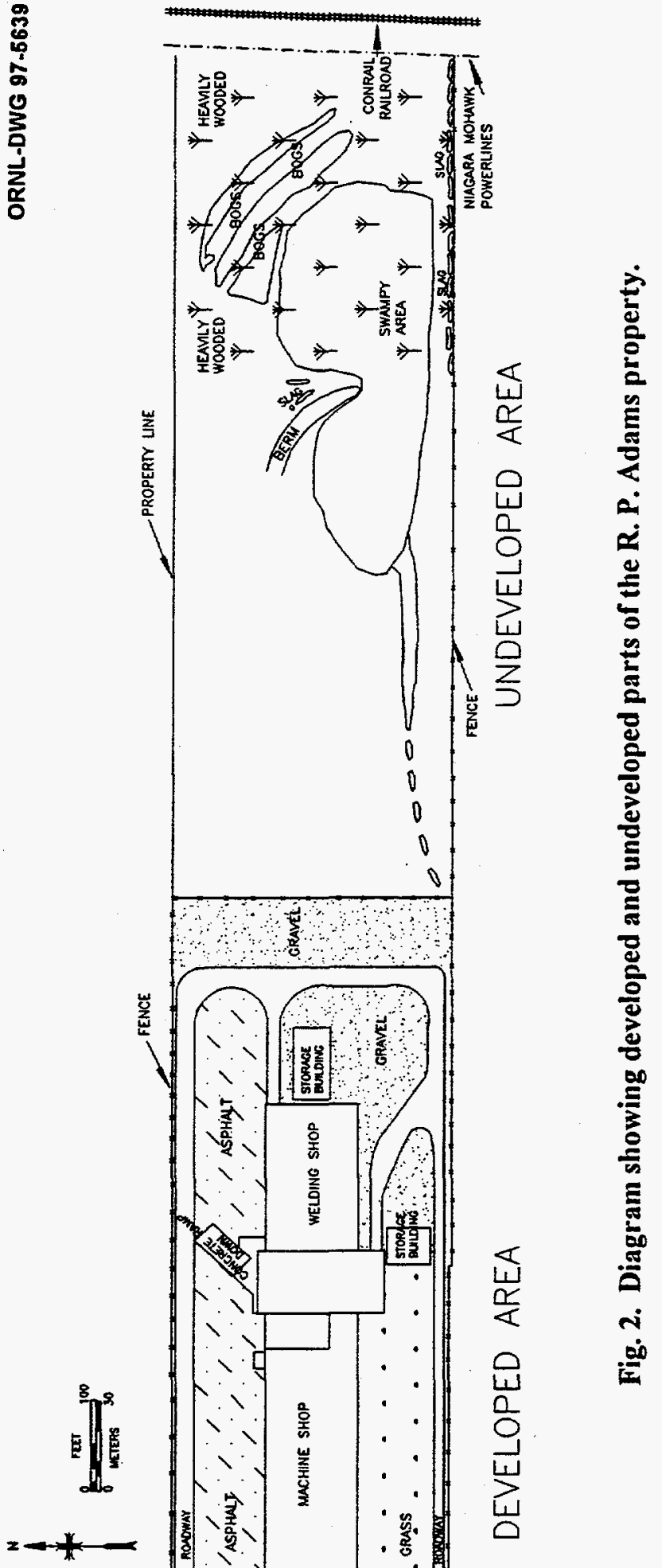

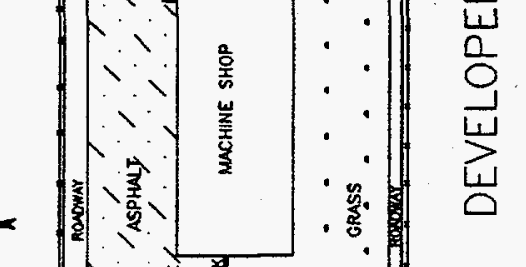

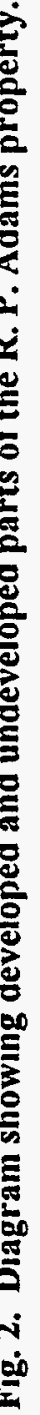




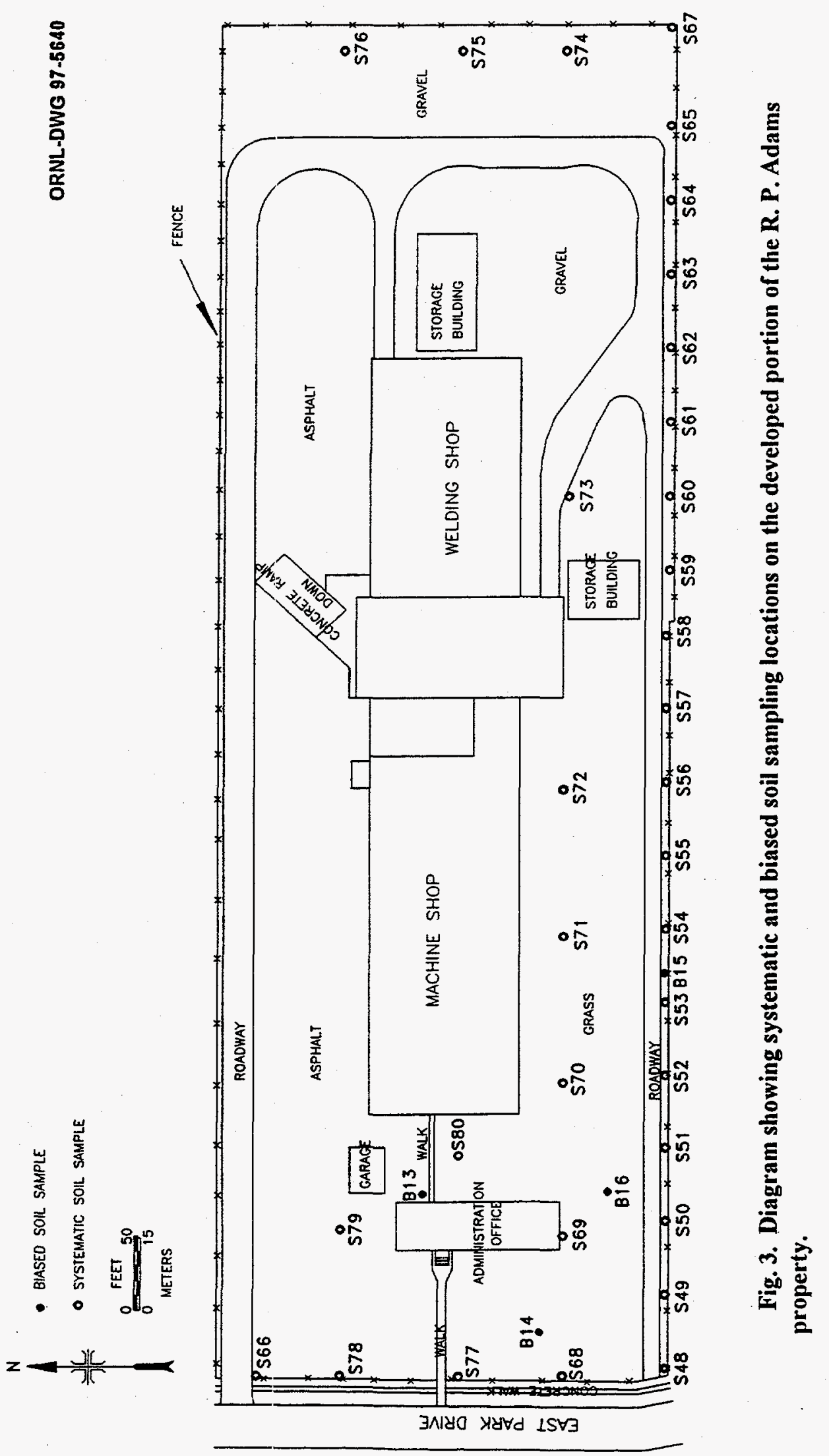




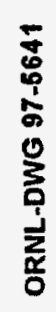
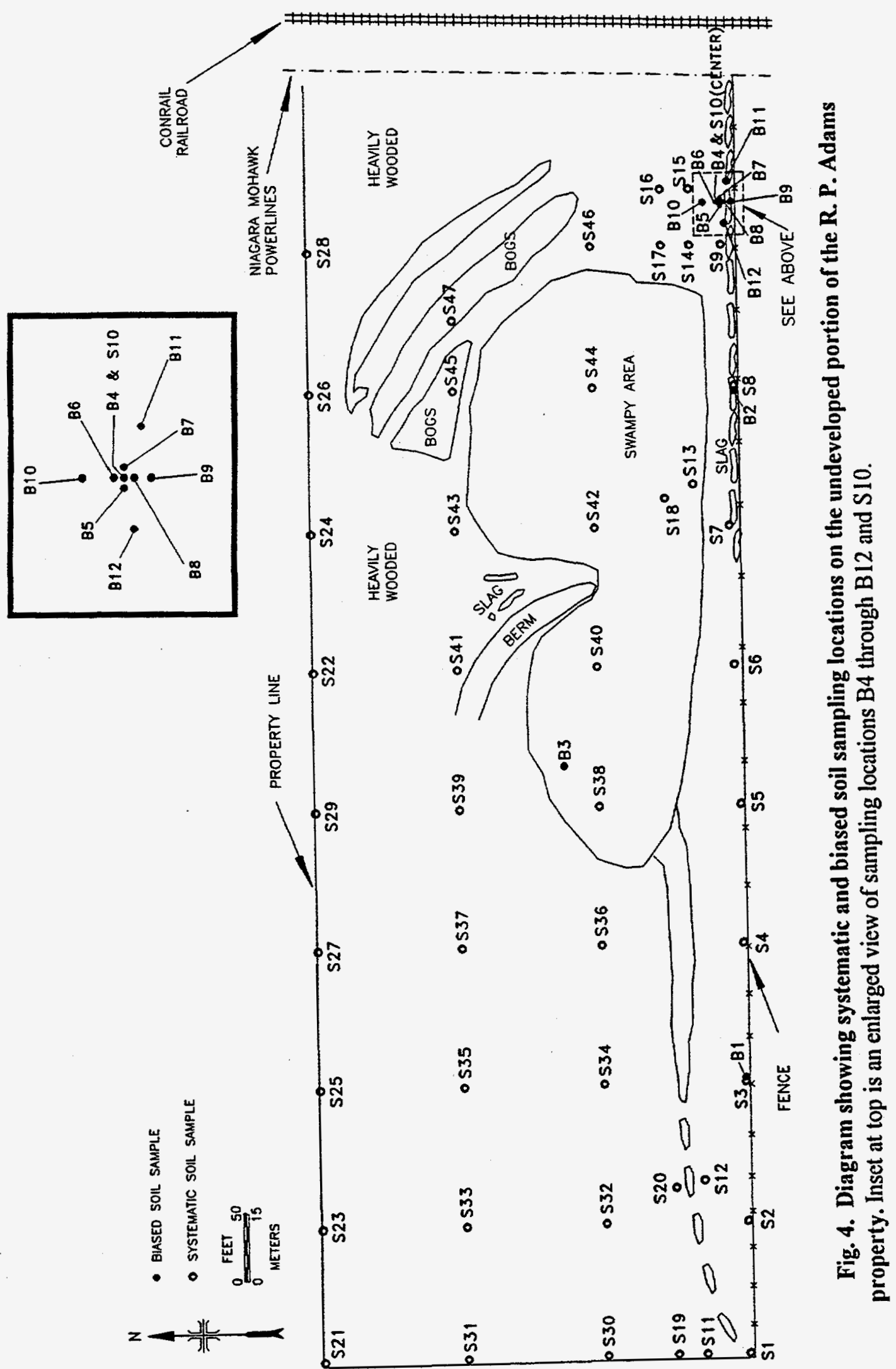
11111111 


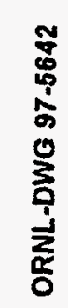

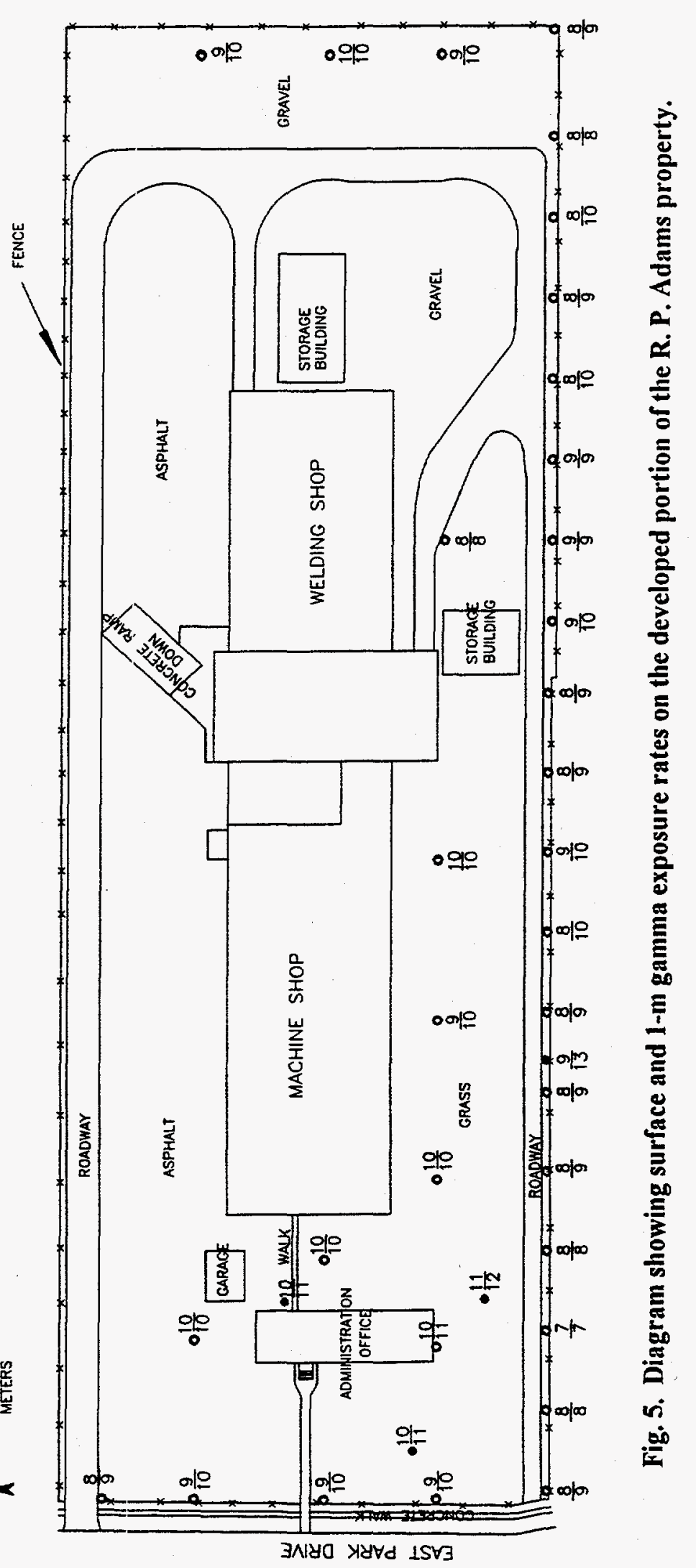




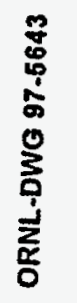
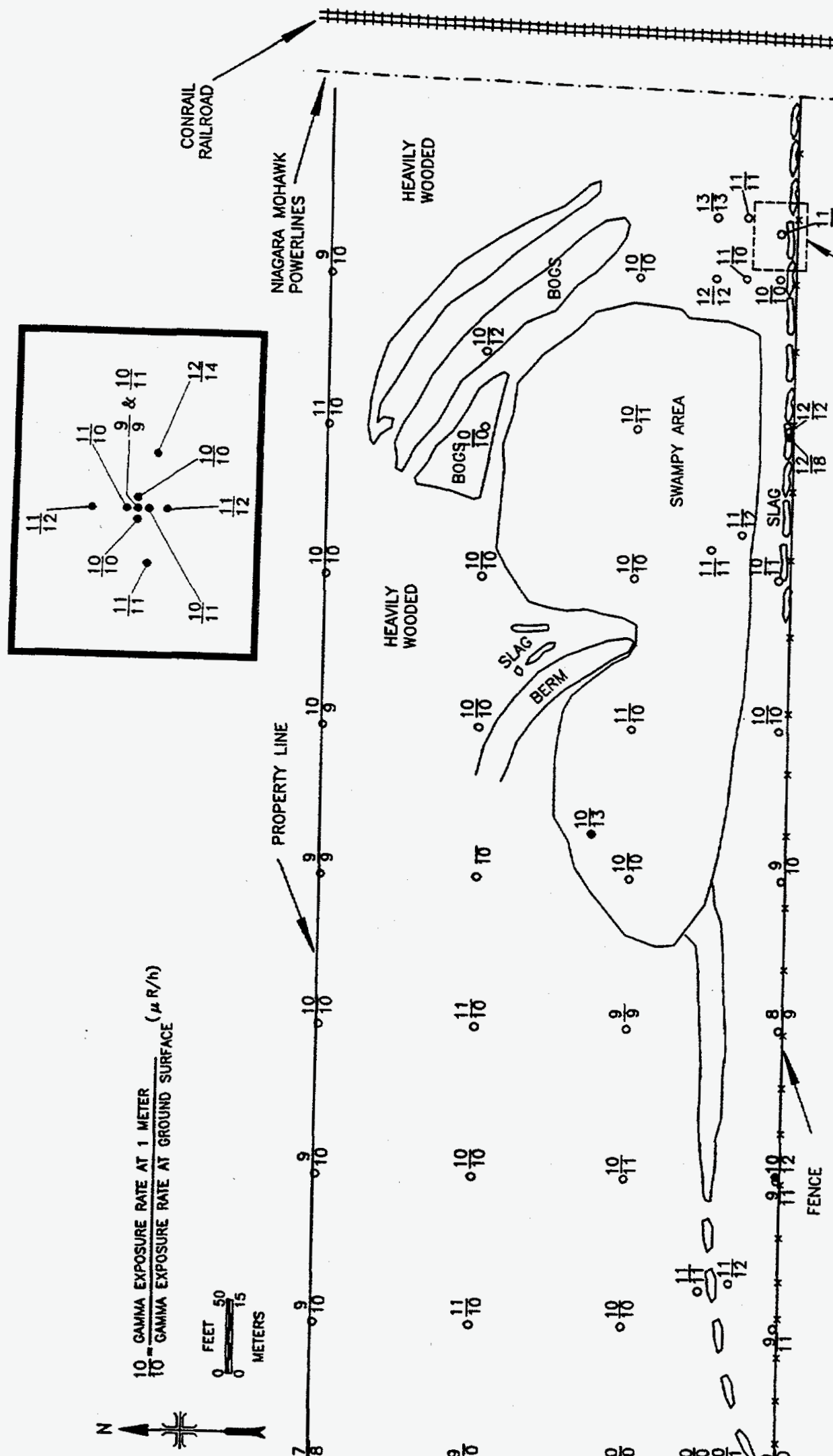

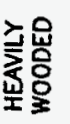

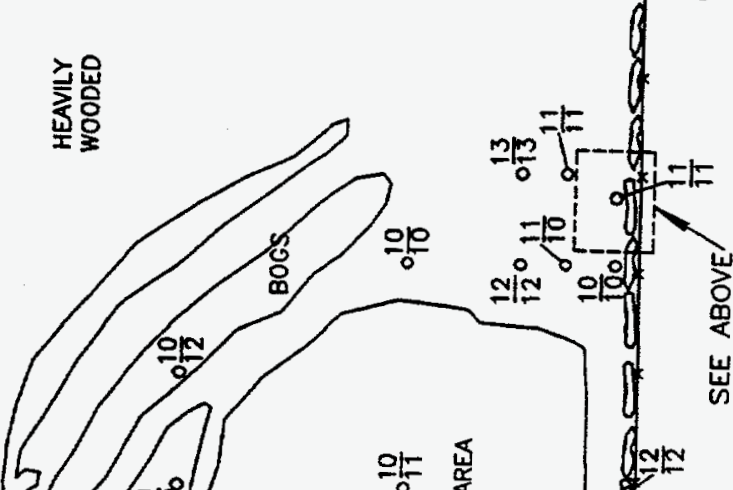
잉 귀꾸 의에

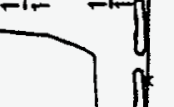


Table 1. Applicable guidelines for protection against radiation

(Limits for uncontrolled areas)

\begin{tabular}{|c|c|c|}
\hline Mode of exposure & Exposure conditions & Guideline value \\
\hline Gamma radiation & $\begin{array}{l}\text { Indoor gamma radiation level } \\
\text { (above background) }\end{array}$ & $20 \mu \mathrm{R} / \mathrm{h}^{a}$ \\
\hline $\begin{array}{l}\text { Radionuclide con- } \\
\text { centrations in soil } \\
\text { (generic) }\end{array}$ & $\begin{array}{l}\text { Maximum permissible con- } \\
\text { centration of the following } \\
\text { radionuclides in soil above } \\
\text { background levels, averaged } \\
\text { over a } 100-\mathrm{m}^{2} \text { area } \\
{ }^{226} \mathrm{Ra} \\
{ }^{232} \mathrm{Th} \\
{ }^{230} \mathrm{Th}\end{array}$ & $\begin{array}{l}5 \mathrm{pCi} / \mathrm{g} \text { averaged over the } \\
\text { first } 15 \mathrm{~cm} \text { of soil below the } \\
\text { surface; } 15 \mathrm{pCi} / \mathrm{g} \text { when } \\
\text { averaged over } 15-\mathrm{cm}-\text { thick } \\
\text { soil layers more than } 15 \mathrm{~cm} \\
\text { below the surface }\end{array}$ \\
\hline Derived concentrations & $\begin{array}{l}\text { Maximum permissible con- } \\
\text { centration of total uranium in } \\
\text { soil above background levels, } \\
\text { averaged over a } 100-\mathrm{m}^{2} \text { area. }\end{array}$ & $60 \mathrm{pCi} / \mathrm{g}^{b}$ \\
\hline $\begin{array}{l}\text { Guideline for non- } \\
\text { homogeneous con- } \\
\text { tamination (used in } \\
\text { addition to the } 100-\mathrm{m}^{2} \\
\text { guideline) }\end{array}$ & $\begin{array}{l}\text { Applicable to locations with } \\
\text { an area } \leq 25 \mathrm{~m}^{2} \text {, with signifi- } \\
\text { cantly elevated concentrations } \\
\text { of radionuclides ("hot spots") }\end{array}$ & $\begin{array}{l}\mathrm{G}_{A}=\mathrm{G}_{i}(100 / \mathrm{A})^{1 / 2}, \\
\text { where } \\
\mathrm{G}_{A}=\text { guideline for "hot } \\
\text { spot" of area }(\mathrm{A}) \\
\mathrm{G}_{i}=\text { guideline averaged } \\
\text { over a } 100-\mathrm{m}^{2} \text { area }\end{array}$ \\
\hline
\end{tabular}

The $20 \mu \mathrm{R} / \mathrm{h}$ shall comply with the basic dose limit ( $100 \mathrm{mrem} / \mathrm{year})$ when an appropriate-use scenario is considered.

${ }^{b}$ Guidelines for uranium are derived on a site-specific basis. A total uranium guideline of $60 \mathrm{pCi} / \mathrm{g}$ will be applied at the R. P. Adams Company site. This corresponds to a ${ }^{238} \mathrm{U}$ concentration of $\sim 30 \mathrm{pCi} / \mathrm{g}$.

${ }^{c}$ Guidelines specify that every reasonable effort shall be made to identify and to remove any source that has a concentration exceeding 30 times the guideline value, irrespective of area (adapted from Revised Guidelines for Residual Radioactive Material at FUSRAP and Remote SFMP Sites, April 1987).

Sources: Adapted from U.S. Department of Energy, DOE Order 5400.5, April 1990; U.S. Department of Energy, Guidelines for Residual Radioactive Material at Formerly Utilized Sites Remedial Action Program and Remote Surplus Facilities Management Program Sites, Rev. 2, March 1987; and U.S. Department of Energy, Radiological Control Manual, DOE/EH-0256T, Rev. 1, April 1994. 
Table 2. Background radiation levels and concentrations of selected radionuclides in soil near Tonawanda, New York

\begin{tabular}{lcc}
\hline \multirow{2}{*}{$\begin{array}{c}\text { Type of radiation measurement } \\
\text { or sample }\end{array}$} & \multicolumn{2}{c}{$\begin{array}{c}\text { Radiation level or radionuclide } \\
\text { concentration }\end{array}$} \\
\cline { 2 - 3 } & Range & Average \\
\hline Gamma exposure rate at & $8-11$ & 9 \\
ground surface $(\mu \mathrm{R} /)^{a}$ & & \\
Concentration of radionuclides & & \\
in soil (pCi/g) & & 1.0 \\
${ }^{238}$ & $0.8-1.1$ & 0.9 \\
${ }^{226} \mathrm{Ra}$ & $0.7-1.1$ & 0.8 \\
${ }^{232} \mathrm{Th}$ & $0.5-0.9$ & \\
\hline
\end{tabular}

aalues obtained from four locations in the Tonawanda area.

Source: R. E. Rodriguez, M. E. Murray, and M. S. Uziel, Results of the Radiological Survey at the Town of Tonowanda Landfill, Tonawanda, New York (TNY001), ORNL/RASA-92/12, Martin Marietta Energy Systems, Inc., Oak Ridge Natl. Lab., October 1992. 
Table 3. Concentrations of selected radionuclides in soil samples collected from the developed west portion of the R. P. Adams property,

Tonawanda, New York

\begin{tabular}{|c|c|c|c|c|c|}
\hline \multirow{2}{*}{$\begin{array}{l}\text { Sample } \\
\mathbb{I D}^{a}\end{array}$} & \multirow{2}{*}{$\begin{array}{c}\text { Grid } \\
\text { location }^{a}\end{array}$} & \multirow{2}{*}{$\begin{array}{l}\text { Depth } \\
\text { (cm) }\end{array}$} & \multicolumn{3}{|c|}{ Radionuclide concentration $(\mathrm{pCi} / \mathrm{g})^{b}$} \\
\hline & & & ${ }^{238} \mathrm{U}$ & ${ }^{226} \mathrm{Ra}$ & ${ }^{232} \mathrm{Th}$ \\
\hline \multicolumn{6}{|c|}{ Systematic samples ${ }^{c}$} \\
\hline S48 & $\mathrm{ON}, \mathrm{OE}$ & $0-15$ & $2.1 \pm 0.4$ & $1.2 \pm 0.09$ & $0.83 \pm 0.1$ \\
\hline S49 & $0 \mathrm{~N}, 50 \mathrm{E}$ & $0-15$ & $1.3 \pm 0.6$ & $1.0 \pm 0.07$ & $0.87 \pm 0.1$ \\
\hline S50 & $\mathrm{ON}, 100 \mathrm{E}$ & $0-15$ & $0.96 \pm 0.5$ & $0.95 \pm 0.08$ & $0.90 \pm 0.1$ \\
\hline S51 & $\mathrm{ON}, 150 \mathrm{E}$ & $0-15$ & $1.2 \pm 0.7$ & $1.2 \pm 0.1$ & $0.89 \pm 0.1$ \\
\hline $\mathrm{S} 52$ & $O N, 200 E$ & $0-15$ & $1.8 \pm 0.9$ & $1.1 \pm 0.1$ & $1.0 \pm 0.1$ \\
\hline S53 & ON, 250E & $0-15$ & $2.6 \pm 0.4$ & $1.1 \pm 0.08$ & $0.90 \pm 0.1$ \\
\hline S54 & $\mathrm{ON}, 300 \mathrm{E}$ & $0-15$ & $2.0 \pm 0.3$ & $1.1 \pm 0.08$ & $0.98 \pm 0.1$ \\
\hline S55 & $\mathrm{ON}, 350 \mathrm{E}$ & $0-15$ & $1.8 \pm 0.3$ & $1.2 \pm 0.1$ & $0.89 \pm 0.1$ \\
\hline S56 & $\mathrm{ON}, 400 \mathrm{E}$ & $0-15$ & $1.9 \pm 0.3$ & $1.1 \pm 0.09$ & $1.2 \pm 0.1$ \\
\hline S57 & ON, 450E & $0-15$ & $1.3 \pm 0.9$ & $1.0 \pm 0.09$ & $1.0 \pm 0.1$ \\
\hline S58 & $0 \mathrm{~N}, 500 \mathrm{E}$ & $0-15$ & $1.8 \pm 0.9$ & $1.0 \pm 0.09$ & $1.1 \pm 0.1$ \\
\hline S59 & $0 \mathrm{~N}, 550 \mathrm{E}$ & $0-15$ & $3.0 \pm 1$ & $1.2 \pm 0.09$ & $1.3 \pm 0.1$ \\
\hline $\mathrm{S} 60$ & ON, $600 \mathrm{E}$ & $0-15$ & $1.9 \pm 0.2$ & $1.2 \pm 0.1$ & $1.1 \pm 0.1$ \\
\hline S61 & $\mathrm{ON}, 650 \mathrm{E}$ & $0-15$ & $4.3 \pm 0.5$ & $1.2 \pm 0.09$ & $1.2 \pm 0.1$ \\
\hline S62 & $\mathrm{ON}, 700 \mathrm{E}$ & $0-15$ & $2.8 \pm 1$ & $1.5 \pm 0.1$ & $1.2 \pm 0.1$ \\
\hline S63 & $0 \mathrm{~N}, 750 \mathrm{E}$ & $0-15$ & $2.6 \pm 0.4$ & $1.2 \pm 0.09$ & $1.1 \pm 0.1$ \\
\hline S64 & $O N, 800 E$ & $0-15$ & $3.0 \pm 1$ & $1.4 \pm 0.09$ & $1.1 \pm 0.1$ \\
\hline S65 & ON, 850E & $0-15$ & $1.6 \pm 0.7$ & $1.2 \pm 0.09$ & $0.70 \pm 0.1$ \\
\hline S66 & $280 \mathrm{~N}, \mathrm{OE}$ & $0-15$ & $1.2 \pm 0.3$ & $0.96 \pm 0.07$ & $0.72 \pm 0.09$ \\
\hline S67 & ON, 920E & $0-15$ & $1.9 \pm 0.2$ & $1.4 \pm 0.09$ & $0.90 \pm 0.1$ \\
\hline S68 & $70 \mathrm{~N}, 0 \mathrm{E}$ & $0-15$ & $1.3 \pm 0.3$ & $1.2 \pm 0.1$ & $1.1 \pm 0.1$ \\
\hline$S 69$ & $70 \mathrm{~N}, 95 \mathrm{E}$ & $0-15$ & $1.0 \pm 0.6$ & $1.1 \pm 0.09$ & $1.1 \pm 0.1$ \\
\hline S70 & $70 \mathrm{~N}, 200 \mathrm{E}$ & $0-15$ & $1.8 \pm 0.9$ & $1.6 \pm 0.1$ & $0.95 \pm 0.1$ \\
\hline S71 & $70 \mathrm{~N}, 300 \mathrm{E}$ & $0-15$ & $1.2 \pm 0.3$ & $1.1 \pm 0.09$ & $0.83 \pm 0.1$ \\
\hline S72 & $70 \mathrm{~N}, 400 \mathrm{E}$ & $0-15$ & $1.5 \pm 0.8$ & $1.0 \pm 0.08$ & $1.1 \pm 0.1$ \\
\hline S73 & $70 \mathrm{~N}, 600 \mathrm{E}$ & $0-15$ & $1.7 \pm 0.4$ & $1.1 \pm 0.1$ & $1.2 \pm 0.1$ \\
\hline S74 & $70 \mathrm{~N}, 900 \mathrm{E}$ & $0-15$ & $1.1 \pm 0.3$ & $0.91 \pm 0.08$ & $1.2 \pm 0.1$ \\
\hline S75 & $140 \mathrm{~N}, 900 \mathrm{E}$ & $0-15$ & $1.0 \pm 0.5$ & $1.0 \pm 0.08$ & $1.1 \pm 0.1$ \\
\hline
\end{tabular}


Table 3 (continued)

\begin{tabular}{|c|c|c|c|c|c|}
\hline \multirow{2}{*}{$\begin{array}{l}\text { Sample } \\
\text { ID }^{a}\end{array}$} & \multirow{2}{*}{$\begin{array}{c}\text { Grid } \\
\text { location }^{a}\end{array}$} & \multirow{2}{*}{$\begin{array}{l}\text { Depth } \\
\text { (cm) }\end{array}$} & \multicolumn{3}{|c|}{ Radionuclide concentration $(\mathrm{pCi} / \mathrm{g})^{b}$} \\
\hline & & & ${ }^{238} \mathrm{U}$ & ${ }^{226} \mathrm{Ra}$ & ${ }^{232} \mathrm{Th}$ \\
\hline S76 & $220 \mathrm{~N}, 900 \mathrm{E}$ & $0-15$ & $1.1 \pm 0.3$ & $1.1 \pm 0.09$ & $1.2 \pm 0.2$ \\
\hline S77 & $140 \mathrm{~N}, 0 \mathrm{E}$ & $0-15$ & $1.7 \pm 0.8$ & $1.2 \pm 0.08$ & $0.92 \pm 0.1$ \\
\hline S78 & $220 \mathrm{~N}, 0 \mathrm{E}$ & $0-15$ & $1.2 \pm 0.7$ & $1.3 \pm 0.1$ & $0.84 \pm 0.1$ \\
\hline S79 & $220 \mathrm{~N}, 100 \mathrm{E}$ & $0-15$ & $0.95 \pm 0.5$ & $0.90 \pm 0.07$ & $0.65 \pm 0.1$ \\
\hline $\mathbf{S} 80$ & $140 \mathrm{~N}, 150 \mathrm{E}$ & $0-15$ & $2.0 \pm 0.3$ & $2.2 \pm 0.1$ & $0.87 \pm 0.1$ \\
\hline \multicolumn{6}{|c|}{ Biased samples ${ }^{d}$} \\
\hline B13 & $165 \mathrm{~N}, 125 \mathrm{E}$ & $0-15$ & $1.9 \pm 0.74$ & $1.2 \pm 0.08$ & $1.0 \pm 0.1$ \\
\hline B14 & $85 \mathrm{~N}, 30 \mathrm{E}$ & $0-15$ & $1.8 \pm 0.8$ & $1.1 \pm 0.09$ & $1.0 \pm 0.1$ \\
\hline B15 & $0.5 \mathrm{~N}, 270 \mathrm{E}$ & $0-15$ & $9.7 \pm 3$ & $1.2 \pm 0.1$ & $1.0 \pm 0.2$ \\
\hline B16 & $40 \mathrm{~N}, 125 \mathrm{E}$ & $0-15$ & $1.6 \pm 0.3$ & $1.2 \pm 0.08$ & $0.96 \pm 0.1$ \\
\hline
\end{tabular}

${ }^{a}$ Sample locations are shown on Figs. 4 and 5.

${ }^{b}$ Indicated counting error is at the $95 \%$ confidence level $( \pm 20)$.

'Systematic samples are collected without regard to gamma radiation levels.

Biased samples are taken from areas shown to have elevated gamma exposure rates. 
Table 4. Concentrations of selected radionuclides in soil samples collected from the undeveloped east portion of the R. P. Adams property,

Tonawanda, New York

\begin{tabular}{|c|c|c|c|c|c|}
\hline \multirow{2}{*}{$\begin{array}{l}\text { Sample } \\
\mathrm{ID}^{a}\end{array}$} & \multirow{2}{*}{$\begin{array}{c}\text { Grid } \\
\text { location }^{a}\end{array}$} & \multirow{2}{*}{$\begin{array}{l}\text { Depth } \\
(\mathrm{cm})\end{array}$} & \multicolumn{3}{|c|}{ Radionuclide concentration $(\mathrm{pCi} / \mathrm{g})^{b}$} \\
\hline & & & ${ }^{238} \mathrm{U}$ & ${ }^{226} \mathrm{Ra}$ & ${ }^{232} \mathrm{Th}$ \\
\hline \multicolumn{6}{|c|}{ Systematic samples ${ }^{c}$} \\
\hline $\mathrm{S} 1$ & $\mathrm{ON}, \mathrm{OE}$ & $0-15$ & $1.6 \pm 0.3$ & $1.4 \pm 0.2$ & $0.77 \bullet 0.09$ \\
\hline S2 & $\mathrm{ON}, 100 \mathrm{E}$ & $0-15$ & $0.74 \pm 0.4$ & $0.80 \pm 0.06$ & $0.65 \pm 0.07$ \\
\hline S3 & $0 \mathrm{~N}, 200 \mathrm{E}$ & $0-15$ & $1.2 \pm 0.8$ & $1.9 \pm 0.1$ & $0.89 \pm 0.1$ \\
\hline S4 & $\mathrm{ON}, 300 \mathrm{E}$ & $0-15$ & $1.9 \pm 0.7$ & $1.7 \pm 0.1$ & $0.83 \pm 0.1$ \\
\hline S5 & $\mathrm{ON}, 400 \mathrm{E}$ & $0-15$ & $0.90 \pm 0.6$ & $1.1 \pm 0.08$ & $0.63 \pm 0.1$ \\
\hline S6 & $3 \mathrm{~N}, 500 \mathrm{E}$ & $0-15$ & $4.7 \pm 2.0$ & $1.1 \pm 0.08$ & $0.79 \pm 0.2$ \\
\hline S7 & $5 \mathrm{~N}, 600 \mathrm{E}$ & $0-15$ & $1.8 \pm 1$ & $1.7 \pm 0.1$ & $1.0 \pm 0.2$ \\
\hline S8A & ON, 700E & $0-15$ & $5.6 \pm 2$ & $2.2 \pm 0.1$ & $1.2 \pm 0.1$ \\
\hline S8B & $0 \mathrm{~N}, 700 \mathrm{E}$ & $15-30$ & $6.4 \pm 2$ & $2.0 \pm 0.1$ & $1.0 \pm 0.2$ \\
\hline $\mathrm{S} 8 \mathrm{C}$ & ON, 700E & $30-45$ & $2.8 \pm 1$ & $1.1 \pm 0.1$ & $1.1 \pm 0.1$ \\
\hline S9A & $8 \mathrm{~N}, 800 \mathrm{E}$ & $0-15$ & $3.8 \pm 0.6$ & $2.6 \pm 0.2$ & $1.2 \pm 0.2$ \\
\hline S9B & $8 \mathrm{~N}, 800 \mathrm{E}$ & $15-30$ & $4.9=1$ & $2.8 \pm 0.2$ & $1.1 \pm 0.1$ \\
\hline S9C & $8 \mathrm{~N}, 800 \mathrm{E}$ & $30-45$ & $4.3 \pm 2$ & $2.1 \pm 0.1$ & $1.2 \pm 0.1$ \\
\hline $\mathrm{S} 10$ & $8 \mathrm{~N}, 830 \mathrm{E}$ & $0-15$ & $16 \pm 1$ & $2.3 \pm 0.2$ & $1.0 \pm 0.2$ \\
\hline S11 & $30 \mathrm{~N}, \mathrm{OE}$ & $0-15$ & $1.2 \pm 0.3$ & $1.0 \pm 0.08$ & $1.0 \pm 0.1$ \\
\hline $\mathrm{S} 12$ & $30 \mathrm{~N}, 130 \mathrm{E}$ & $0-15$ & $1.3 \pm 0.3$ & $1.0 \pm 0.09$ & $1.0 \pm 0.1$ \\
\hline $\mathrm{S} 13$ & $30 \mathrm{~N}, 630 \mathrm{E}$ & $0-15$ & $3.6 \pm 0.5$ & $1.3 \pm 0.09$ & $0.99 \pm 0.1$ \\
\hline S14 & $30 \mathrm{~N}, 800 \mathrm{E}$ & $0-15$ & $5.0 \pm 2$ & $2.2 \pm 0.2$ & $0.90 \pm 0.2$ \\
\hline S15 & $30 \mathrm{~N}, 840 \mathrm{E}$ & $0-15$ & $6.6 \pm 2$ & $1.9 \pm 0.2$ & $1.1 \pm 0.2$ \\
\hline S16 & $50 \mathrm{~N}, 840 \mathrm{E}$ & $0-15$ & $6.1 \pm 2$ & $2.2 \pm 0.2$ & $1.0 \pm 0.2$ \\
\hline S17A & $50 \mathrm{~N}, 800 \mathrm{E}$ & $0-15$ & $4.3 \pm 0.5$ & $1.5 \pm 0.2$ & $1.1 \pm 0.1$ \\
\hline S17B & $50 \mathrm{~N}, 800 \mathrm{E}$ & $15-30$ & $1.2 \pm 0.8$ & $1.0 \pm 0.1$ & $1.2 \pm 0.1$ \\
\hline S17C & $50 \mathrm{~N}, 800 \mathrm{E}$ & $30-45$ & $1.3 \pm 0.3$ & $1.0 \pm 0.08$ & $1.4 \pm 0.1$ \\
\hline $\mathrm{S} 18$ & $50 \mathrm{~N}, 620 \mathrm{E}$ & $0-15$ & $4.5 \pm 2$ & $1.2 \pm 0.1$ & $1.1 \pm 0.2$ \\
\hline S19 & $50 \mathrm{~N}, 0 \mathrm{E}$ & $0-15$ & $1.2 \pm 0.6$ & $1.1 \pm 0.08$ & $1.0 \pm 0.1$ \\
\hline $\mathbf{S} 20$ & $50 \mathrm{~N}, 125 \mathrm{E}$ & $0-15$ & $1.7 \pm 0.3$ & $1.1 \pm 0.1$ & $1.1 \pm 0.1$ \\
\hline S21 & $295 \mathrm{~N}, \mathrm{OE}$ & $0-15$ & $1.0 \pm 0.8$ & $0.85 \pm 0.08$ & $0.74 \pm 0.1$ \\
\hline $\mathrm{S} 22$ & $\begin{array}{l}500 \mathrm{ft} \mathrm{E} \text { of } \mathrm{NW} \text { corner } \\
\text { of property at perimeter }\end{array}$ & $0-15$ & $3.6 \pm 2$ & $1.3 \pm 0.09$ & $0.94 \pm 0.1$ \\
\hline $\mathrm{S} 23$ & $\begin{array}{l}100 \mathrm{ft} E \text { of } \mathrm{NW} \text { corner } \\
\text { of property at perimeter }\end{array}$ & $0-15$ & $1.3 \pm 0.3$ & $1.0 \neq 0.09$ & $0.69 \pm 0.1$ \\
\hline
\end{tabular}


Table 4 (continued)

\begin{tabular}{|c|c|c|c|c|c|}
\hline \multirow{2}{*}{$\begin{array}{l}\text { Sample } \\
\text { ID }^{a}\end{array}$} & \multirow{2}{*}{$\begin{array}{c}\text { Grid } \\
\text { location }^{a}\end{array}$} & \multirow{2}{*}{$\begin{array}{l}\text { Depth } \\
\text { (cm) }\end{array}$} & \multicolumn{3}{|c|}{ Radionuclide concentration $(\mathrm{pCi} / \mathrm{g})^{b}$} \\
\hline & & & ${ }^{238} \mathrm{U}$ & ${ }^{226} \mathrm{Ra}$ & ${ }^{232} \mathrm{Th}$ \\
\hline S24 & $\begin{array}{l}600 \mathrm{ftE} \text { of NW corner } \\
\text { of property at perimeter }\end{array}$ & $0-15$ & $3.2 \pm 0.5$ & $1.5 \pm 0.1$ & $1.1 \pm 0.2$ \\
\hline S25 & $\begin{array}{l}200 \mathrm{ft} E \text { of NW corner } \\
\text { of property at perimeter }\end{array}$ & $0-15$ & $2.1 \pm 0.4$ & $1.1 \pm 0.1$ & $0.89 \pm 0.1$ \\
\hline S26 & $\begin{array}{l}700 \mathrm{ft} \mathrm{E} \text { of NW corner } \\
\text { of property at perimeter }\end{array}$ & $0-15$ & $2.9 \pm 0.4$ & $1.5 \pm 0.1$ & $0.96 \pm 0.1$ \\
\hline S27 & $\begin{array}{l}300 \mathrm{ft} \mathrm{E} \text { of NW corner } \\
\text { of property at perimeter }\end{array}$ & $0-15$ & $1.5 \pm 0.3$ & $1.2 \pm 0.09$ & $1.1 \pm 0.1$ \\
\hline S28 & $\begin{array}{l}800 \mathrm{ft} E \text { of NW comer } \\
\text { of property at perimeter }\end{array}$ & $0-15$ & $1.9 \pm 0.4$ & $1.5 \pm 0.1$ & $0.89 \pm 0.1$ \\
\hline S29 & $\begin{array}{l}400 \mathrm{ft} \mathrm{E} \text { of NW comer } \\
\text { of property at perimeter }\end{array}$ & $0-15$ & $1.4 \pm 0.3$ & $1.2 \pm 0.1$ & $1.1 \pm 0.1$ \\
\hline S30 & $100 \mathrm{~N}, 0 \mathrm{E}$ & $0-15$ & $1.2 \pm 0.3$ & $1.1 \pm 0.08$ & $0.98 \pm 0.1$ \\
\hline S31 & $200 \mathrm{~N}, 0 \mathrm{E}$ & $0-15$ & $1.7 \pm 0.7$ & $1.1 \pm 0.08$ & $1.0 \pm 0.1$ \\
\hline S32 & $100 \mathrm{~N}, 100 \mathrm{E}$ & $0-15$ & $1.4 \pm 0.6$ & $1.1 \pm 0.08$ & $1.1 \pm 0.1$ \\
\hline S33 & $200 \mathrm{~N}, 100 \mathrm{E}$ & $0-15$ & $1.4 \pm 0.3$ & $1.2 \pm 0.09$ & $0.97 \pm 0.1$ \\
\hline S34 & $100 \mathrm{~N}, 200 \mathrm{E}$ & $0-15$ & $1.6 \pm 0.4$ & $1.2 \pm 0.09$ & $1.0 \pm 0.1$ \\
\hline S35 & $200 \mathrm{~N}, 200 \mathrm{E}$ & $0-15$ & $1.7 \pm 1$ & $1.2 \pm 0.09$ & $1.1 \pm 0.1$ \\
\hline S36 & $100 \mathrm{~N}, 300 \mathrm{E}$ & $0-15$ & $1.4 \pm 0.6$ & $1.2 \pm 0.08$ & $0.34 \pm 0.08$ \\
\hline S37 & $200 \mathrm{~N}, 300 \mathrm{E}$ & $0-15$ & $1.3 \pm 0.8$ & $1.1 \pm 0.1$ & $1.1 \pm 0.1$ \\
\hline S38 & $100 \mathrm{~N}, 400 \mathrm{E}$ & $0-15$ & $5.3 \pm 2$ & $1.6 \pm 0.1$ & $1.1 \pm 0.1$ \\
\hline S39 & $200 \mathrm{~N}, 400 \mathrm{E}$ & $0-15$ & $1.5 \pm 0.4$ & $1.2 \pm 0.09$ & $1.1 \pm 0.1$ \\
\hline $\mathrm{S} 40$ & $100 \mathrm{~N}, 500 \mathrm{E}$ & $0-15$ & $3.4 \pm 0.5$ & $1.4 \pm 0.09$ & $1.1 \neq 0.1$ \\
\hline S41 & $200 \mathrm{~N}, 500 \mathrm{E}$ & $0-15$ & $4.1 \pm 0.6$ & $1.5 \pm 0.1$ & $1.0 \pm 0.1$ \\
\hline $\mathrm{S} 42$ & $100 \mathrm{~N}, 600 \mathrm{E}$ & $0-15$ & $3.9 \pm 2$ & $1.8 \pm 0.1$ & $1.3 \pm 0.2$ \\
\hline S43 & $200 \mathrm{~N}, 600 \mathrm{E}$ & $0-15$ & $5.0 \pm 0.6$ & $1.8 \pm 0.1$ & $1.0 \pm 0.2$ \\
\hline S44 & $100 \mathrm{~N}, 700 \mathrm{E}$ & $0-15$ & $4.2 \pm 1$ & $2.0 \pm 0.1$ & $1.2 \pm 0.1$ \\
\hline S45 & $200 \mathrm{~N}, 700 \mathrm{E}$ & $0-15$ & $2.7 \pm 0.4$ & $1.6 \pm 0.1$ & $1.0 \pm 0.1$ \\
\hline S46 & $100 \mathrm{~N}, 800 \mathrm{E}$ & $0-15$ & $1.5 \pm 0.9$ & $1.5 \pm 0.1$ & $1.1 \pm 0.1$ \\
\hline S47 & $200 \mathrm{~N}, 750 \mathrm{E}$ & $0-15$ & $1.3 \pm 0.7$ & $1.7 \pm 0.1$ & $0.97 \pm 0.1$ \\
\hline
\end{tabular}


Table 4 (continued)

\begin{tabular}{|c|c|c|c|c|c|}
\hline \multirow{2}{*}{$\underset{\mathrm{ID}^{a}}{\text { Sample }}$} & \multirow{2}{*}{$\begin{array}{c}\text { Grid } \\
\text { location }^{a}\end{array}$} & \multirow{2}{*}{$\begin{array}{l}\text { Depth } \\
(\mathrm{cm})\end{array}$} & \multicolumn{3}{|c|}{ Radionuclide concentration $(\mathrm{pCi} / \mathrm{g})^{b}$} \\
\hline & & & ${ }^{238} \mathrm{U}$ & ${ }^{226} \mathrm{Ra}$ & ${ }^{232} \mathrm{Th}$ \\
\hline \multicolumn{6}{|c|}{ Biased samples ${ }^{d}$} \\
\hline $\mathrm{B} 1$ & ON, 203E & $0-15$ & $1.7 \pm 0.3$ & $1.9 \pm 0.1$ & $1.0 \pm 0.1$ \\
\hline $\mathrm{B} 2 \mathrm{~A}$ & $0 \mathrm{~N}, 696 \mathrm{E}$ & $0-15$ & $3.0 \pm 1$ & $2.4 \pm 0.1$ & $2.2 \pm 0.2$ \\
\hline $\mathrm{B} 2 \mathrm{~B}$ & ON, 696E & $15-30$ & $3.4 \pm 1$ & $2.3 \pm 0.1$ & $1.7 \pm 0.2$ \\
\hline B3A & $125 \mathrm{~N}, 430 \mathrm{E}$ & $0-15$ & $5.6 \pm 2$ & $2.5 \pm 0.1$ & $3.5 \pm 0.2$ \\
\hline B3B & $125 \mathrm{~N}, 430 \mathrm{E}$ & $15-30$ & $3.0 \pm 1$ & $2.5 \pm 0.1$ & $3.5 \pm 0.3$ \\
\hline B4 & $8 \mathrm{~N}, 830 \mathrm{E}$ & $0-15$ & $6.6 \pm 1$ & $1.8 \pm 0.1$ & $1.0 \pm 0.2$ \\
\hline B5 & $8 \mathrm{~N}, 827 \mathrm{E}$ & $0-15$ & $4.2 \pm 0.9$ & $1.5 \pm 0.1$ & $0.97 \pm 0.2$ \\
\hline B6 & $11 \mathrm{~N}, 830 \mathrm{E}$ & $0-15$ & $3.3 \bullet 1$ & $1.4 \pm 0.1$ & $0.91 \pm 0.1$ \\
\hline B7 & $8 \mathrm{~N}, 833 \mathrm{E}$ & $0-15$ & $6.0 \pm 2$ & $2.2 \pm 0.2$ & $0.96 \pm 0.2$ \\
\hline $\mathrm{B} 8 \mathrm{~A}$ & $5 \mathrm{~N}, 830 \mathrm{E}$ & $0-15$ & $11 \pm 4$ & $2.6 \pm 0.2$ & $1.1 \pm 0.2$ \\
\hline B8B & $5 \mathrm{~N}, 830 \mathrm{E}$ & $15-30$ & $10 \pm 2$ & $3.4 \pm 0.2$ & $1.1 \pm 02$ \\
\hline B9A & $\mathrm{ON}, 830 \mathrm{E}$ & $0-15$ & $2.6 \pm 1$ & $1.9 \pm 0.1$ & $1.2 \pm 0.1$ \\
\hline B9B & ON, $830 E$ & $15-30$ & $3.3 \pm 1$ & $1.9 \pm 0.1$ & $1.0 \pm 0.1$ \\
\hline B9C & ON, $830 \mathrm{E}$ & $30-45$ & $4.9 \pm 2$ & $2.2 \pm 0.1$ & $0.87 \pm 0.1$ \\
\hline $\mathrm{B} 10$ & $20 \mathrm{~N}, 830 \mathrm{E}$ & $0-15$ & $8.5 \pm 2$ & $2.3 \pm 0.2$ & $1.0 \pm 0.2$ \\
\hline $\mathrm{Bl} 1 \mathrm{~A}$ & $3 \mathrm{~N}, 845 \mathrm{E}$ & $0-15$ & $6.4 \pm 0.6$ & $3.9 \pm 0.2$ & $3.1 \pm 0.2$ \\
\hline B11B & $3 \mathrm{~N}, 845 \mathrm{E}$ & $15-30$ & $8.9 \pm 3$ & $3.7 \pm 0.2$ & $1.7 \pm 0.2$ \\
\hline B12 & $5 \mathrm{~N}, 815 \mathrm{E}$ & $0-15$ & $4.8 \pm 2$ & $3.2 \pm 0.2$ & $1.2 \pm 0.2$ \\
\hline
\end{tabular}

"Sample locations are shown on Figs. 4 and 5.

'Indicated counting error is at the $95 \%$ confidence level $( \pm 2 \sigma)$.

'Systematic samples are collected without regard to gamma radiation levels.

Biased samples are taken from areas shown to have elevated gamma exposure rates. 